\title{
Pemaknaan Kebahagiaan oleh Remaja Broken Home
}

\author{
Sarah Hafiza, Marty Mawarpury \\ Universitas Syiah Kuala, Jl. Teuku Nyak Arief, Syiah Kuala, Kota Banda Aceh \\ e-mail: sarahhafiza96@yahoo.com
}

\begin{abstract}
Happiness is the expectation for every person including teenager. However, parental divorce may have impact on teenagers' happiness. The aim of this study is to know happiness in teenager whose parents divorced. Data for this research were obtained using qualitative method with case study design. Subject was selected using purposive sampling technique. The respondent was a male teenager with divorced parents. Data collection was carried out through interview. The results showed that the respondent had three aspects of happiness are life is pleasant, meaningful, and engaging.
\end{abstract}

Keywords: happiness, divorce, teenager, qualitative research

\begin{abstract}
Abstrak
Kebahagiaan merupakan dambaan bagi setiap manusia termasuk remaja. Namun, perceraian orang tua dapat berdampak terhadap kebahagiaan remaja. Tujuan dari penelitian ini adalah untuk melihat kebahagiaan pada remaja yang orang tuanya bercerai. Data pada penelitian ini diperoleh dengan menggunakan metode kualitatif dengan desain studi kasus. Pemilihan subjek menggunakan teknik purposive sampling. Responden pada penelitian ini merupakan seorang remaja laki-laki yang orang tuanya telah bercerai. Pengumpulan data penelitian dengan cara wawancara. Hasil penelitian ini menunjukkan bahwa responden memiliki tiga aspek kebahagiaan yaitu, kehidupan yang menyenangkan, kehidupan yang bermakna, dan keterlibatan diri.
\end{abstract}

Kata kunci: kebahagiaan, perceraian, remaja, penelitian kualitatif

\section{Pendahuluan}

Setiap individu pasti mengharapkan kebahagiaan dalam hidupnya, bahkan hampir setiap individu mendambakan kehidupan yang bahagia. Menurut Seligman (2006) kebahagiaan dikenal dalam Psikologi Positif, namun sampai saat ini masih banyak perbedaan pendapat mengenai bagaimana kebahagiaan bisa terjadi dan apa penyebabnya. Pada dasarnya kebahagiaan merupakan bagian dari kesejahteraan, yang biasa disebut sebagai hedonik. Menurut Seligman (2006) kebahagiaan dipengaruhi oleh dua emosi dasar yaitu emosi positif dan emosi negatif pada diri seseorang. Lebih lanjut ditunjukkan dari hasil penelitian yang dilakukan oleh Diener dan Ryan (2009) individu akan merasa lebih bahagia apabila berada di sekitar orang lain.
Kebahagiaan akan dirasakan semua kalangan usia, terutama bagi remaja. Hurlock (2009) membagi masa remaja menjadi masa remaja awal (13 hingga 16 tahun) dan remaja akhir (16 atau 17 hingga 18 tahun). Terdapat perbedaan masa remaja disebabkan pada masa remaja akhir individu telah mencapai transisi perkembangan yang lebih mendekati masa dewasa. Remaja diartikan sebagai masa transisi antara anak-anak dan dewasa, yang dapat memengaruhi segala aspek kehidupan seperti perubahan biologis, kognitif, dan sosioemosional.

Menurut Hurlock (2009) remaja dengan penyesuaian diri yang buruk cenderung paling tidak bahagia selama masa remajanya, hingga secara perlahan berkurang ketika dapat mengatasi masalah tersebut, maka periode ketidakbahagiaan juga akan berkurang. Ketidakbahagiaan pada 
remaja menjadi suatu permasalahan yang harus dibahas. Hal ini didukung oleh Hones dan Meredith (dalam Elfida, Lestari, Diamera, Angraeni, \& Islami, 2014) yang mengatakan bahwa mengingat tumbuh kembang remaja yang cenderung tidak bahagia menjadi relevan membahas mengenai isu ketidakbahagiaan pada remaja.

Banyak hal yang terjadi pada usia remaja baik dalam hal positif maupun negatif. Menurut Giyanti dan Wardani (2016) masa remaja merupakan masa yang sangat baik untuk mengembangkan segala potensi positif yang dimiliki, seperti bakat, kemampuan, minat, dan nilai-nilai hidup. Namun di sisi lain, banyak remaja yang mengabaikan kesempatannya untuk melakukan hal-hal baik, yang justru remaja melakukan hal sebaliknya, seperti malarikan diri dari rumah, bolos, balapan liar, berkelahi, melakukan perilaku agresif secara fisik maupun verbal, dan juga merokok, hingga menggunakan zat-zat terlarang (Ningrum, 2013).

Berbagai alasan yang diberikan para remaja untuk menjawab perbuatannya, salah satunya faktor keluarga. Menurut Kartono (2010) keluarga memegang peranan penting dalam perkembangan anak, karena keluarga merupakan kelompok pertama dalam kehidupan manusia. Pada keluarga yang broken home anak selalu menjadi atau dijadikan korban. Kondisi ini akan sangat berpengaruh pada tumbuh kembang anak dan dapat memengaruhi proses pembentukan karakter dan kepribadiannya (Astuti \& Anganthi, 2016).

Menurut Amato dan Sobolewski (2011) remaja yang mengalami perceraian orang tua cenderung mengalami ketidakbahagiaan, rendahnya kontrol diri, dan tidak memiliki kepuasan dalam hidup. Selain itu, remaja dengan kondisi keluarga broken home sering mengalami tekanan mental seperti depresi, hal ini yang menyebabkan biasanya anak memiliki perilaku sosial yang buruk (Aziz, 2015). Merupakan suatu kenyataan yang tidak menyenangkan bagi remaja ketika berada pada masa pencarian jati diri dan memiliki masalah pribadi sebagai remaja, justru harus dihadapkan pada kenyataan bahwa orang tuanya bercerai (Novi, 2015).

Penelitian yang dilakukan oleh Aziz (2015) di Kota Banda Aceh menunjukkan bahwa remaja dengan keluarga broken home memiliki perilaku-perilaku yang menyimpang, seperti tidak sopan, tidak mengerjakan tugas sekolah, tidak memiliki motivasi untuk belajar, dan suka mencari perhatian dari orang lain. Namun di sisi lain, pada remaja dengan kondisi rumah tangga broken home malah tidak menunjukkan perubahan yang signifikan atas kejadian yang dialaminya disebabkan ada sosok yang menggantikan kedua orang tuanya, seperti nenek, kakek, paman, tante, dan keluarga lainnya (Astuti \& Anganthi, 2016).

Bagi remaja, perceraian adalah sesuatu yang tidak mudah dan membutuhkan tahapan atau proses yang membantu remaja untuk menerima keputusan kedua orang tua untuk bercerai (Woofolk, dalam Aminah, 2012). Tujuan dari penelitian ini adalah ingin melihat makna kebahagiaan pada remaja yang orang tuanya telah bercerai. Penelitian ini dilakukan dengan metode wawancara dan observasi.

\section{Kebahagiaan}

Menurut Seligman (2002) kebahagiaan merupakan perasaan positif yang akan mendorong seseorang untuk melakukan berbagai tindakan yang positif. Kebahagiaan sebagai konsep yang mengacu pada emosi positif yang dirasakan individu serta aktivitas positif yang tidak memiliki komponen perasaan negatif, misalnya ketika individu terlibat dalam kegiatan yang sangat disukai.

Seligman (2002) menyebutkan kebahagiaan memiliki tiga aspek. Aspek pertama adalah kehidupan yang menyenangkan (pleasant life). Individu yang bahagia adalah individu yang memiliki pengalaman menyenangkan yang tinggi, rendahnya pengalaman yang tidak menyenangkan, dan 
memiliki kemampuan untuk meningkatkan kebahagiaan di masa depan.

Aspek kedua adalah kehidupan yang bermakna (meaningful life). Individu memeroleh makna dalam hidup ketika hidup yang dijalani dijadikan pengalaman yang memiliki tujuan, berarti, dan dapat dimengerti. Hidup yang bermakna dapat diperoleh dengan terlibat secara aktif dan membangun hubungan positif dengan orang lain. individu yang memiliki kebahagiaan tidak terfokus pada diri sendiri ketika melakukan setiap aktivitas melainkan juga mementingkan kepentingan individu yang lain.

Aspek ketiga adalah keterlibatan diri (engaged life). Keterlibatan diri mengacu pada kondisi dimana individu melibatkan seluruh aspek dalam diri (fisik, kognitif, dan emosional) untuk turut serta dalam aktivitas yang dilakukan. Keterlibatan penuh tidak hanya dalam lingkup karier, tetapi juga dalam aktivitas lain seperti hobi dan aktivitas bersama keluarga. Individu yang terlibat secara aktif dalam berbagai pekerjaan membuat individu lebih bahagia.

Seligman (2002) juga menjelaskan bahwa terdapat dua faktor yang memengaruhi kebahagiaan, yaitu faktor internal dan faktor eksternal. Faktor internal kebahagiaan, meliputi: kepuasan akan masa lalu; optimis akan masa depan; kebahagiaan pada masa sekarang. Faktor eksternal, meliputi: uang; perkawinan; kehidupan sosial; emosi negatif; usia; kesehatan; pendidikan, iklim, ras, dan jenis kelamin; serta agama.

\section{Perceraian}

Menurut Prodjohamidjojo (2002) perceraian adalah putusnya suatu perkawinan yang sah di depan hakim pengadilan berdasarkan syarat-syarat yang ditentukan undang-undang. Selain itu, menurut Subekti (1985) perceraian adalah sebuah penghapusan perkawinan yang diputuskan oleh hakim atau tuntutan salah satu satu pihak dalam perkawinan tersebut.
Menurut Syarifuddin (2006) terdapat empat bentuk perceraian. Pertama, perceraian atas kehendak Allah sendiri melalui matinya salah satu pasangan. Kematian salah seorang suami atau istri menyebabkan berakhirnya hubungan perkawinan. Kedua, perceraian atas kehendak suami karena alasan tertentu dan dinyatakan dengan ucapan tertentu. Perceraian dalam bentuk ini disebut talaq. Ketiga, perceraian atas kehendak istri, karena melihat sesuatu yang menghendaki putusnya perkawinan sedangkan suami tidak berkehendak untuk itu. Keinginan perceraian disampaikan istri dengan cara tertentu, hal ini diterima oleh suami dan dilanjutkan dengan ucapan untuk bercerai. Putusnya perkawinan dengan cara ini disebut khulu'. Keempat, perceraian atas kehendak hakim sebagai pihak ketiga setelah melihat adanya sesuatu pada suami atau istri yang menandakan tidak dapatnya hubungan perkawinan dilanjutkan. Putusnya perkawinan dalam bentuk ini disebut fasakh.

Menurut Maryanti (2007), dampak perceraian bagi anak diantaranya anak menjadi mudah marah, frustrasi, dan ingin melampiaskannya dengan melakukan halhal yang berlawanan dengan peraturanperaturan seperti memberontak dan lain sebagainya. Selain itu, bila anak tinggal dengan ibu, anak akan kehilangan figur otoritas ayah. Ketika figur otoritas itu menghilang, anak seringkali tidak begitu takut dengan ibunya. Dampak lain adalah anak menjadi kehilangan jati diri sosialnya atau identitas sosial, mendapatkan status sebagai anak cerai memberikan suatu perasaan berbeda dari anak-anak lain.

Menurut Hetherington, Cox, dan Cox (1985) akibat langsung yang timbul dari perceraian adalah distres emosional dan masalah perilaku seperti kemarahan, kebencian, kecemasan, dan depresi serta hasil-hasil penelitian tentang perceraian banyak yang mengungkapkan bahwa anak beresiko tinggi mengalami masalahmasalah perkembangan psikologis, tingkah 
laku, sosial, dan akademik dibandingkan dengan keluarga sepasang orang tua yang tidak bercerai.

\section{Metode Penelitian}

Penelitian ini berfokus pada variabel kebahagiaan yaitu individu yang memiliki perasaan positif dan tidak adanya perasaan negatif yang dapat mendorong individu untuk melakukan berbagai tindakan yang positif.

Keabsahan data penelitian melalu empat tahap. Tahap pertama yakni validitas internal (kredibilitas) didapat dengan melakukan konfirmasi kembali dengan responden; melakukan studi dalam kondisi alamiah responden; diskusi, menurut Moleong (2013) diskusi dapat menghasilkan pandangan kritis terhadap penelitian; referensi, dengan cara membandingkan temuan dengan studi serupa; member checking, pengecekan data yang diperoleh kepada responden untuk mengetahui kesesuaian data.

Tahap kedua adalah validitas eksternal (transferability). Menurut Poerwandari (2007), Creswell (2010), serta Satori dan Komariah (2011), transferability berfungsi untuk melihat sejauhmana penelitian dapat diterapkan pada populasi dan sampel yang diambil.

Tahap ketiga, reliabilitas (dependability). Dependability adalah ukuran reliabilitas yang dilakukan dengan cara audit terhadap seluruh proses penelitian seperti, pelaporan proses dan hasil secara detil. Dalam hal ini dosen dengan bidang penelitian yang sesuai bertindak sebagai auditor.

Tahap keempat adalah objektivitas (confirmability). Objektivitas dalam penelitian untuk melihat data yang diperoleh dapat dilacak kebenarannya dan sumber informasi yang jelas. Hal ini dipenuhi dengan cara menyusun catatan lapangan, mendeskripsikan data, analisis dan pemaknaan, serta melaporkan proses pengumpulan data.
Penelitian ini menggunakan pendekatan kualitatif, jenis fenomenologi. Pemilihan subjek dilakukan dengan menggunakan teknik purposive sampling dengan kriteria, berupa remaja berusia 13-18 tahun, orang tua yang telah bercerai, berdomisili di Banda Aceh dan bersedia menjadi responden penelitian. Tiga subjek memenuhi tiga kriteria pertama, dan hanya satu subjek yang memenuhi keempat kriteria subjek penelitian. Data diperoleh melalui wawancara dengan protokol semi terstruktur. Peneliti melakukan wawancara terhadap responden tersebut yang merupakan seorang remaja laki-laki berusia 17 tahun yang kedua orang tuanya telah bercerai selama 12 tahun. Data yang terkumpul dibuat dalam bentuk verbatim sesuai dengan hasil rekaman. Verbatim tersebut kemudian dimasukkan dalam sebuah tabel. Setelah itu dilakukan proses koding pada setiap pernyataan yang diberikan responden.

\section{Hasil Penelitian dan Pembahasan}

Berdasarkan hasil wawancara menunjukkan bahwa responden menggambarkan kebermaknaan dari ketiga aspek kebahagiaan pada remaja.

\section{Kehidupan yang Menyenangkan (Pleasant Life)}

Individu yang bahagia adalah individu yang memiliki pengalaman menyenangkan yang tinggi, hal ini sesuai dengan pernyataan responden ketika diberikan pertanyaan mengenai pengalaman yang paling menyenangkan "dari usia tiga belas tahun udah kerja sendiri, biar pun kalau orang lihat sedih gitu, tapi bagi $R$ pribadi senang gitu, maksudnya.." (TRA, 29 Mei 2017, b.372-374), "dari kakek, banyak supportnya gitu.." (TRA, 29 Mei 2017, b.345). Rendahnya pengalaman yang tidak menyenangkan, dan memiliki kemampuan untuk meningkatkan kebahagiaan di masa depan hal ini ditunjukkan pada hasil wawancara pada saat pertanyaan mengenai rencana yang akan dilakukan di masa yang 
akan datang, "awalnya mau cari kerja dulu, biayai adik yang kecil, terus.. pokoknya mau jadi kepalalah (oke..) mau bertanggung jawab untuk semua, itu udah bahagia kak." (TRA, 29 Mei 2017, b.465468).

Kebahagiaan merupakan perasaan positif dirasakan individu yang akan mendorong seseorang untuk melakukan berbagai tindakan yang positif dan disebabkan oleh aktivitas positif yang tidak memiliki komponen perasaan negatif (Seligman, 2002). Individu yang bahagia adalah individu yang memiliki pengalaman menyenangkan yang tinggi, rendahnya pengalaman yang tidak menyenangkan, dan memiliki kemampuan untuk meningkatkan kebahagiaan di masa depan.

Pengalaman yang menyenangkan bagi responden diantaranya dengan mendapatkan dukungan dari keluarga dan teman untuk menambah semangat responden dalam menjalani kehidupan sehari-hari. Selain itu, bertemu atau berkumpul dengan keluarga dan teman juga membuat responden merasa lebih senang. Responden juga merasa bahagia ketika terlibat dalam kegiatan yang sangat disukai, seperti melakukan hobinya yaitu menyanyi ataupun membahagiakan ibunya.

\section{Kehidupan yang Bermakna (Meaningful Life)}

Individu memeroleh makna dalam hidup ketika hidup yang dijalani dijadikan pengalaman yang memiliki tujuan, berarti, dan dapat dimengerti. Hidup yang bermakna dapat diperoleh dengan terlibat secara aktif dan membangun hubungan positif dengan orang lain, hal ini sesuai dengan pernyataan responden mengenai apa yang dilakukan ketika bersama teman "Yaa. ngumpul gitu kak.. ajak teman-teman ngumpul, pokoknya $R$ gak terlalu pikir kesitu, $R$ jalani aja, apalagi kalau udah teman-teman kan itu yaa waktu itu ya waktu itu, gak mikir waktu yang lalu.." (TRA, 29 Mei 2017, b.445-449). Selanjutnya, individu yang memiliki kebahagiaan tidak terfokus pada diri sendiri ketika melakukan setiap aktivitas melainkan juga mementingkan kepentingan individu yang lain.

Kebahagiaan juga ditandai dengan individu memeroleh makna dalam hidup ketika hidup yang dijalani dijadikan pengalaman yang memiliki tujuan, berarti, dan dapat dimengerti. Hidup yang bermakna dapat diperoleh dengan terlibat secara aktif dan membangun hubungan positif dengan orang lain. Individu yang memiliki kebahagiaan tidak terfokus pada diri sendiri ketika melakukan setiap aktivitas melainkan juga mementingkan kepentingan individu yang lain. Responden mengatakan bahwa pengalamannya bekerja adalah hal yang menyenangkan, responden mengatakan dengan mempunyai pengalaman bekerja di usia muda ia dapat memiliki pengalaman yang lebih dan di masa yang akan datang responden tidak terkejut lagi dengan dunia pekerjaan.

\section{Keterlibatan Diri (Engaged Life)}

Keterlibatan diri mengacu pada kondisi dimana individu melibatkan seluruh aspek dalam diri (fisik, kognitif, dan emosional) untuk turut serta dalam aktivitas yang dilakukan seperti pada hasil wawancara ketika membahas mengenai kegiatan yang biasa dilaksanakan di sekolah "Waktu jadi ketua OSIS banyak kegiatannya, ngurusngurus itu, cuma karena sekolah baru majukan jadi agak susah dikit.." (TRA, 29 Mei 2017, b.766-768), responden juga menceritakan beberapa kegiatan lainnya yang diakukan pada saat di sekolah maupun di rumah. Keterlibatan penuh tidak hanya dalam lingkup karier, tetapi juga dalam aktivitas lain seperti hobi dan aktivitas bersama keluarga sesuai dengan pernyataan dari responden mengenai hobinya, "Hobinya.. nyanyi juga hobi kak, musik.." (TRA, 29 Mei 2017, b.560). Individu yang terlibat secara aktif dalam berbagai pekerjaan membuat individu lebih bahagia.

Dari hasil wawancara yang telah dilakukan, responden bercerita mengenai 
pengalamannya menjadi ketua OSIS dan selalu melibatkan beberapa murid dalam perlombaan yang diadakan di luar sekolah, selain itu responden sebagai ketua OSIS juga selalu membuat perlombaan antar sekolah di sekolahnya. Dengan melakukan hobinya yaitu bernyanyi, responden mengatakan dapat membuatnya lebih bersemangat. Hal ini juga menunjukkan salah satu aspek kebahagiaan yaitu keterlibatan diri. Keterlibatan diri mengacu pada kondisi dimana individu melibatkan seluruh aspek dalam diri (fisik, kognitif, dan emosional) untuk turut serta dalam aktivitas yang dilakukan. Keterlibatan penuh tidak hanya dalam lingkup karier, tetapi juga dalam aktivitas lain seperti hobi dan aktivitas bersama keluarga.

Individu yang terlibat secara aktif dalam berbagai pekerjaan membuat individu lebih bahagia. Perceraian kedua orang tua memengaruhi kebahagiaan responden. Ia menceritakan bahwa dirinya mengalami ketakutan dan kebingungan saat masih kecil akibat dari berpisahnya kedua orang tua, merasakan kurangnya kasih sayang dari sosok ibu, dan pernah dijauhi oleh teman-teman ketika masih berada di bangku sekolah dasar, sehingga sejak SMP sampai dengan sekarang responden hanya menceritakan kisahnya kepada beberapa teman dekatnya saja, karena menurut responden tidak semua teman dapat memahami keadaannya saat ini. Hal ini sesuai dengan hasil penelitian yang dilakukan oleh Glenn dan Krammer (dalam Primasti \& Wirastari, 2013) bahwa perceraian orang tua yang dialami oleh remaja akan mengakibatkan perasaan tidak nyaman, rendahnya self-esteem, dan beberapa karakteristik yang serupa yang akhirnya berujung pada psychological wellbeing yang rendah. Efek yang dialami remaja tersebut nantinya akan berlanjut hingga dewasa.

Amato dan Sobolewski (2001) juga mengungkapkan bahwa remaja yang mengalami perceraian orang tua cenderung tidak memiliki kepuasan dalam hidup, lemahnya self-control, dan tidak ada kebahagiaan. Beberapa hal tersebut nantinya akan memengaruhi tiap dimensi yang berada pada psychological well-being (Primasti \& Wirastari, 2013). Dalam hal ini responden sempat mengalami konflik dengan ayahnya disebabkan responden merasa ayahnya tidak bertanggung jawab terhadap keluarga.

Sikap ibu tiri responden yang menunjukkan ketidaksukaan terhadap dirinya menyebabkan responden memiliki persepsi yang negatif mengenai ibu tirinya. Responden juga mengalami konflik dengan ayah tirinya dimana responden diusir dari rumah oleh ayah tirinya karena konfik yang terjadi antara ayah tiri, ibu, dan dirinya sendiri.

Maramis (2000) menambahkan sikap orang tua yang kurang memperhatikan anak akan mengakibatkan anak yang bersangkutan akan merasa ditolak dan tidak dicintai. Mereka mempunyai hasrat untuk membalas dendam disertai dengan perasaan yang tidak bahagia dan agresif karena ketika anak menunjukkan perilaku yang baik ia tidak mendapatkan perhatian dan kasih sayang; maka ia mencari jalan lain untuk mendapatkan perhatian di luar rumah yaitu melalui cara yang negatif dan dapat mengganggu orang lain. Anak merasa tidak bahagia dan dipenuhi konflik batin hingga anak mengalami frustrasi, agresif, dan nakal.

Seligman (2002) menjelaskan ada dua faktor dalam kebahagiaan, faktor internal dan faktor eksternal. Faktor internal dijelaskan dalam tiga jenis sedangkan faktor eksternal terdiri dari delapan jenis. Salah satu jenis dari faktor kebahagiaan secara eksternal adalah uang. Beberapa kali responden menceritakan tentang masalah ekonomi keluarganya. Responden mengatakan ayahnya tidak memberikan uang untuk keluarganya, responden tidak memiliki uang untuk membayar uang kas, tidak memiliki uang untuk makan, bahkan responden harus cuti sekolah selama satu tahun disebabkan ketidakmampuan dalam 
hal ekonomi. Responden juga mulai bekerja ketika usianya 13 tahun untuk mencukupi kebutuhannya.

Dalam menjalani kehidupan sehariharinya saat ini, responden mengaku tidak ingin memikirkan tentang perceraian kedua orang tuanya dan juga permasalahan hidupnya. Responden ingin menjalankan hidupnya dengan tenang dan bahagia.

\section{Simpulan dan Saran}

\section{Simpulan}

Hasil penelitian menunjukkan bahwa responden memiliki tiga aspek kebahagiaan yaitu, kehidupan yang menyenangkan, kehidupan yang bermakna, dan keterlibatan diri. Hal ini ditunjukkan oleh pengalaman menyenangkan yang dialami responden ketika ia mendapatkan dukungan dari keluarga dan teman untuk menambah semangat responden dalam menjalani kehidupan sehari-hari. Ia juga pernah menjabat sebagai ketua OSIS di sekolahnya serta pernah menyelenggarakan dan mengikuti berbagai kegiatan.

\section{Saran}

Penelitian selanjutnya diharapkan dapat menyediakan waktu yang lebih lama agar penelitian yang dilakukan lebih optimal dan data yang didapatkan lebih mendalam. Peneliti juga menyarankan untuk mempertimbangkan variabel pendukung lainnya yang berkaitan dengan kebahagiaan pada remaja.

\section{Daftar Pustaka}

Amato, P. R. \& Sobolewski, J. M. (2001). The effects of divorce and marital discord on adult children's psychological well-being. American Sociological Review, 66(6), 900921.

Aminah, Andayani, T. R., \& Karyanta, N. A. (2012). Proses penerimaan anak (remaja akhir) terhadap perceraian orang tua dan konsekuensi psikososial yang menyertainya.
Jurnal Ilmiah Psikologi

Candrajiwa, 1(3).

Astuti, Y., Rachmah, N., \& Anganthi, N. (2016). Subjective well-being pada remaja keluarga broken home. Jurnal Penelitian Humaniora, 17(2), 161-175.

Aziz, M. (2015). Perilaku sosial anak remaja korban broken home dalam berbagai perspektif. Jurnal AlIjtimaiyyah, 1(1), 30-50.

Creswell, J. W. (2010). Research design pendekatan kualitatif, kuantitatif, dan mixed. Yogyakarta: Pustaka Pelajar.

Diener, E. \& Ryan, K. (2009). Subjective well being: A general overview. South African Journal of Psychology. 39(4), 391-406.

Elfida, D., Lestari, Y. I., Diamera, A., Angraeni, R., \& Islami, S. (2014). Hubungan baik dengan orang yang signifikan dan kontribusinya terhadap kebahagiaan remaja Indonesia. Jurnal Psikologi. 10(2), 66-73.

Giyati \& Wardani, I. R. K. (2016). Ciri-ciri kepribadian dan kepatutan sosial sebagai prediktor subjective wellbeing (kesejahteraan subyektif) pada remaja akhir. Analitika, 8(1), 10-24.

Hetherington, E. M., Cox, M., \& Cox, R. (1985). Long term effect of divorce and remarriage on the adjustment of children. Journal of the American Academy of Child Psychiatry, 24(5), 518-530.

Hurlock, E. B. (2009). Psikologi perkembangan suatu pendekatan sepanjang rentang kehidupan. Jakarta: Erlangga.

Kartono, K. (2010). Psikologi wanita jilid 2: Mengenal wanita sebagai ibu dan nenek. Bandung: Mandar Maju.

Maramis W. F. (2000). Catatan ilmu kedokteran jiwa. Surabaya: Airlangga University Press. 
Maryanti. (2007). Keluarga bercerai dan intensitas interaksi anak terhadap orang tuanya. Jurnal Harmoni Sosial, 1(2).

Moleong, L. J. (2013). Metodologi penelitian kualitatif. Bandung: Remaja Rosdakarya.

Ningrum, P. R. (2013). Perceraian orang tua dan penyesuaian diri remaja. $E$ Journal Psikologi. 1(1), 69-79.

Novi (2015). Remaja korban perceraian. Diakses pada tanggal 23 Mei 2017 dari

http://www.kompasiana.com/novi/r emaja-korbanperceraian_54ff0e52a33311471c50f $9 \mathrm{a} 1$

Poerwandari, E. K. (2007). Pendekatan kualitatif untuk penelitian perilaku manusia. Jakarta: LPSP3 Fakultas Psikologi Universitas Indonesia.

Primasti, K. A. \& Wrastari, A. T. (2013). Dinamika psychological well-being pada remaja yang mengalami perceraian orang tua ditinjau dari family conflict yang dialami. Jurnal Universitas Airlangga, 2(3), 120127.

Prodjohamidjojo, M. (2002). Hukum perkawinan Indonesia. Jakarta: Perpustakaan Nasional.

Satori, D. \& Komariah, A. (2011). Metode penelitian kualitatif. Bandung: Alfabeta.

Seligman, M. E. P. (2006). Authentic happiness. Bandung: Mizan Media Utama.

Seligman, M. E. P. (2002). Authentic happiness: Using the new positive psychology to realize your potential for lasting fulfillment. New York: The Free Press.

Subekti. (1985). Hukum perjanjian. Jakarta: Intermasa.

Syarifuddin, A. (2006). Hukum perkawinan Islam di Indonesia. Jakarta: Prenada Media. 